\title{
The Islamic university
}

\author{
Is there a winning combination?
}

\author{
Haggai Erlich \\ Department of Middle Eastern and African History, Tel Aviv University \\ Tel Aviv, Israel \\ Email: erlich@post.tau.ac.il
}

\begin{abstract}
Modern universities have developed in the Middle East along Western models. They departed from the religious concepts of knowledge upon which the old Islamic institutions of learning had been founded. As Islam returned in our days to inspire politics and culture throughout the region, many are looking for a proper combination. The paper discusses the ideas of one relevant and prominent Islamic thinker.
\end{abstract}

Keywords-university; Middle East; Islam; knowledge; science; humanities; Arabism; ZakiBadawi; Al-Azhar; Madrasa; Egypt; Turkey; Iran

\section{THE ARAB UNIVERSITIES[1]}

At the beginning of the twenty-first century, the Middle Eastern university is still undergoing change and seeking its identity. In the main academic centers of the Sunni Arab world, most universities were modeled after Cairo University as it was between the World Wars, and as it changed during the Nasserist era and again in the 1970s. The residue from the different eras, and the complexity of today's problems, have created a tension between traditions of a national, liberal academy, of a revolutionary Arab academy, and an academy saturated with Islamic heritage. The latter seeks coexistence between universal technological sciences and local traditional foundations. By and large, the universities in the Arab world have become centers that offer a professional education and that have rapidly expanded the ranks of the middle classes in the various countries. However, the level of the research and teaching conducted therein is still subjected to serious criticism. To the outside observer, it seems that since the days of the constitutional nationalism of the first half of the twentieth century, the Arab university has distanced itself from its original affinity with Western culture, and that the characteristics that it adopted during the Nasserist era, during the rapid expansions of the 1970s, and during the present-day return to political Islam, have undermined its ability to sustain infrastructures for research as understood in the West.[2]

\section{TURKEY AND IRAN}

Until recently, Turkey represented a significantly different direction. Atatürk built the Turkish university as part of his doctrine that there is no progress without Western culture. The academic system in his country has remained true to that legacy, and so far has mostly not gone through the changes and shifts in definitions like the rest of the Arabspeaking world. The Turkish academic system has been and remains notable for the challenging practical matters of student admissions and resource allocation, but it has remained basically oriented towards Europe, both in its teaching and research. The system is right now being challenged by a government that represents a return to Islam and the space of the Middle East. This challenge has not yet eaten away at the Western foundations of the Turkish academy, but it fits well with the fast-moving process of bringing Turkey back into the Middle East. It would seem that developments in the Turkish academy will impact on the future of the universities in the region.[3]

Since the Islamic revolution, Iran has gone in a different, or even contradictory direction. It sees the university, as created under the Shah with its Western orientation, as a foreign agent and as representing a hostile culture. It has tried, and keeps trying, to change the universities, to undermine its conceptual format, and fill it with Islamic content. These efforts reflect a return to traditional interpretations of knowledge and science, while at the same time making rapid technological achievements. From the outset the Islamic regime has aspired to reshape the university by prioritizing Islamic culture and constructing it in a way that will advance Iranian hegemony in the Middle East and ensure an Islamic victory over the West. The struggle over the university in Iran is not over, but the thesis posited by the revolutionary regime in this regard is quite clear. What is less clear is the outcome of this internal struggle between the regime and those who defend the university as a stronghold of science and universal thinking, and the influence of this Iranian drama on the formation of the academy throughout the entire Middle East.[4]

\section{PROFESSOR BADAWI'S IDEAS}

What, then, is the direction of the university in the Islamic space of the Middle East? There are some contemporary Muslim thinkers who believe that it would be possible to create an Islamic university that organizationally integrates advanced science with their authentic culture. That this kind of integration will be made possible if Islam itself opens up, and holds out the prospect of a promising future not only for Muslims, but for the entire world. One of the leading figures in this regard was Prof. Zaki Badawi (19222006), whose own life is a fine representation of the idea of bridging Islam and the West: he was born in Egypt, graduated from al-Azhar, held a $\mathrm{PhD}$ in Islamic philosophy from London University, founded the Muslim College in 
London, was awarded a KBE by the Queen of England, set up international forums for Islamic-Christian-Jewish dialogue, and was an accomplished advocate for a moderate and open form of Islam.

Badawi laid out his vision for the future of the Islamic academy in an article published in 1997 in the magazine, alKalima: "The role of Islamic universities in advancing Islam in the next century".[2] According to Badawi, if the Muslims could come to draw on a moderate and non-fanatical Islam, they would be able to extract themselves from their current marginal location in world science. Furthermore, together, moderate Islam and the Islamic university could lead the world in scientific progress in the century to come. For him, the West created science and separated it from religion, thereby producing a technological world that is alienated from the human soul:

Science is a tremendous force that has been given to mankind. People do not use this force, and have not always used it, for the general good, or even for their own good and that of their surroundings. One of the reasons for this is that modern science has rebelled against God... Science represents itself as a boat traversing the sea at great speed, though there is no one at the wheel to direct it. So it is sailing very quickly, covering great distances, but aimlessly. And I believe that we have no choice but to bring religion back into the scientist's laboratory and reinstate morality in the industrialist's factory.

For Badawi, having so decisively detached one from the other, the West no longer knows how to integrate science and religion. He argues that Buddhism cannot fill the vacuum because it lacks an ordered set of laws, such as Islamic shar'ia. Because there is no alternative to rejoining spirituality and science, and because that is necessarily how things will be in the twenty-first century, "those of us in Islamic societies and Islamic universities must be among the leaders of this trend... Islam is the religion most suited to leading this tendency towards integration". The key, according to Badawi, lies with the Islamic universities that are trying to do precisely this.

What is an "Islamic university"? As someone who spent his life in the world of Islam, lecturing in East Asia, West Africa, and everywhere in between, Badawi defines the Islamic university as an academic institution that is committed both to spreading religious belief, da'wa, and to advancing the practical sciences and learning the languages of the West. This kind of institutional apparatus has been in existence for some time, and has become much larger during recent decades. Examples of it include "Al-Azhar, the universities of Al-Qarawiyyin [Fes, Morocco], and AlZaytuna [Tunis], as well as the colleges in Najaf [Iraq] and Qom [Iran], and the recently-opened universities in a number of Arab countries, such as Saudi Arabia, Syria or Iraq, and the universities in Jordan and Yemen and places further afield, such as Malaysia, Indonesia, India and Pakistan - all the universities that define themselves as institutions that prepare people for Islamic worship".

Badawi hopes that these and other institutions will provide the foundations for change. However, he points out, none of these institutions has worked out how to integrate science and Islam properly. Badawi describes his return to Al-Azhar University as a lecturer, and his disappointment:

What was the purpose of the reform at Al-Azhar [in 1961]? The purpose was to train up religious scholars who are familiar with the sciences, and scientists or doctors who are familiar with religion. The purpose was to integrate religion and science at the academic level, so that Al-Azhar would train doctors who would also spread religion, and engineers who would be knowledgeable about Islam... to create a situation whereby a graduate of Al-Azhar will not feel helpless in the face of modern societies, which are developing quickly and influenced by the exact sciences. Unfortunately, however... the project has not realized the philosophy behind it... the desired integration between religion and science has not been achieved. All that has been achieved is proximity - the practical faculties are next to the religious ones, but there is no reciprocity between the two. On the contrary - the religious faculties at Al-Azhar are becoming ever more ignorant of the sciences compared to the time when they were not located right next to the practical faculties...

According to Badawi, the Islamic universities created a kind of proximity between the sciences and Islam but not any real integration whereby scientists are also religious, and religious people are also scientists. Only such people will introduce morality and usefulness into the scientific method, and only Islam can produce such people.

For Badawi, despite their failure so far, Islamic universities are Islam's only hope of recapturing a position of leadership in the world. Universities that imitate the West will be unable to integrate the scientific and the spiritual. Precisely because Islam did not separate science from religion in the past it is able to create the man and the scientist of the twenty-first century. Therefore, the Islamic universities have to make a huge effort to adapt science. This effort will only succeed if Islamic countries are democratized and the achievements of world science are translated into Islamic terms:

If Islamic people are truly to participate in decisionmaking processes, and if... they have a reasoned and levelheaded leadership, I believe that the program or the picture that I painted above [the integration of science and religion in the universities and the return of Islam to a position of global leadership] will be realized within the Islamic nation... If we wish to advance Islam in the twenty-first century, we have no choice but to know the language of that century, that is, the language of science - which we must learn... Only Islam can lead modern society... If we fail, others will do so in our stead, and we will come to regret that.

\section{CONCLUSION}

Badawi's vision of harmonious coexistence between religion and science, which will crown Islam as a world leader, is thus dependent on deep changes. His assertion that progress is not possible without democratization accords 
with the lessons of history. It appears to me, therefore, that without liberated thought, women's equality, individual freedom, representative politics, freedom of information and organization, and the sanctification of the rights and sovereignty of the "other", it is doubtful whether a productive academy will emerge. If the fields of knowledge that deal with people and society as free systems are marginalized, then it will be impossible to join the West, or even really compete with it. Without interpreting science in terms of freely aspiring to uncover that which is hidden, instead of memorizing that which is already known, there will be no innovative Islamic universities in positions of leadership. Badawi's comments also imply that in order to advance science in the Islamic world, it must open itself fully to the achievements of Western science, its concepts, tools, and values. In fact, in order to do all this, the Muslims must redefine themselves, though without giving up on their identity.

If this happens, then the history of modern higher education in the Middle East would come full circle. The adoption of higher education in Western terms throughout the nineteenth century led to the emergence of modern nationalist movements which shaped the history of higher education and its various metamorphoses. Meanwhile, Islamic societies went through crises of identity, in terms of both the definition of their society as a whole, and the definition of the university. Badawi's utopian vision tries to plot a path to a single solution to the question of general and academic identity. If Islam is flexible enough to include the values of science as formulated in the West and can integrate them with its own renewal, then maybe the circle will be closed with a return to both the sources and progress. However, for such a vision to be realized, even partially, those in support of Badawi's program must first overcome those who seek victory for Islam in its old format and those who lead their countries by deploying modern apparatuses of oppression. Can we identify the beginning of such a change?

\section{REFERENCES}

[1] This article is based on my Hebrew book, Hagai Erlich, Generations of Rage, Students and Universities in the Middle East. The Open University of Israel, 2012, and on my English book: Students and Universities in Twentieth Century Egyptian Politics, London 1989. .

[2] The section on the Arab universities is based on various articles in Arab press and in the internet, for example: Wa'd al-'Asqari, "The role of the university in society", from the "Al-Hiwar al-Mutamadin" website: http://ahewar.org/debat/show.art.asp?aid=113120 24.10.2007; Al-Itijah Al-Muakis, 24.11.2009: Failure of Arab Universities, http://zavita.co.il/archives/503.

[3] The section on the Turkish universities is based on various articles in Turkish press and in the internet, for example Gülsün Atanur Baskan, "The Development of Higher Education in Turkey", http://yordam.manas.kg/ekitap/pdf/Manasdergi/sbd/sbd3/sbd-3-02.pdf; H. Dundara and D.R. Lewis, "Equity, Quality and Efficiency Effects of Reform in Turkish Higher Education", Higher Education Policy 12 (1999), pp. 343-366.

[4] The section on the Iranian universities is based on various articles in Iranian press and in the internet, for example. See also: R. Razavi, "The Cultural Revolution in Iran, with Close Regard to the Universities, and its Impact on the Student Movement", Middle Eastern Studies 45/1 (2009), pp. 1-17.
[5] Z. Badawi, "The role of Islamic universities in advancing Islam in the next century", Al-Kalima 17 (Autumn 1997): http://www.kalema.net/v1/?rpt=55\&art 